\title{
ЭТАПЫ РАЗВИТИЯ ИНТЕРКУЛЬТУРНОГО ОБРАЗОВАНИЯ В ТУРЦИИ
}

\section{Манахов Ильяс Анвярович}

старший преподаватель кафедры восточных языков ФГБОУ ИВО «Московский государственный гуманитарно-экономический университет»

\begin{abstract}
Аннотация: Выделяются этапы развития интеркультурного образования в Османской империи и Турецкой Республике, связанные с экономическим и политическим развитием Турции. Рассматриваются особенности каждого этапа. Обосновывается необходимость использования понятия «интеркультурное образование» в отношении развития образовательной системы Турции.

Ключевые слова: Интеркультурное образование, система образования в Турции, этапы развития интеркультурного образования.
\end{abstract}

\section{STAGES OF DEVELOPMENT OF INTERCULTURAL EDUCATION IN TURKEY}

Manakhov Ilyas A.

\begin{abstract}
The stages of development of intercultural education in the Ottoman Empire and the Republic of Turkey, associated with the economic and political development of Turkey, are highlighted. The features of each stage are considered. The necessity of using the concept of "intercultural education" in relation to the development of the Turkish educational system is substantiated.

Key words: Intercultural education, education system in Turkey, stages of development of intercultural education.

Усиливающаяся межнациональная и межкультурная напряженность в мире, обусловленная экономическими, политическими, социально-психологическими процессами требует усиленного внимания ученых-педагогов к образовательному процессу. Г. Гачев, изучая национальные образы мира,
\end{abstract}


обратил внимание на парадокс, который заключается в том, что, с одной стороны, мы наблюдаем сближение народов и культур, с другой - обострение «национальной чувствительности». [2] Э. Ласло называет новый формат жизни человечества «интерсуществование», утверждая, что оно охватило всю планету и выражается в зависимости государств и сообществ друг от друга в плане экономического и экологического благосостояния и территориальной безопасности [5] .

Интеркультурное образование, обеспечивающее как культурную идентичность, так и межкультурную толерантность, становится фокусом внимания педагогической науки и практики. Целью интеркультурного образования является воспитание интеркультурной личности, сохраняющей свою национальную культуру и индивидуальность, но понимающей многомерность мира и признающей и организующей партнерство представителей различных культур [3].

Термин «интеркультурное образование» появился сравнительно недавно, однако сама идея эмпирически была обозначена еще в древности, когда расширение географического пространства в связи с войнами, торговлей и др. заставляло древних мыслителей задаваться вопросами синтеза единства и разнообразия культур и народов. И.Г. Гердер писал: «Мы проследили исторический путь некоторых народов, и нам стало ясно, насколько различны, в зависимости от времени, места и прочих обстоятельств, цели всех их устремлений... и тем не менее мы видим, что во всем творит лишь одно начало человеческий разум... А потому одна цепь культуры соединяет своей кривой и все время отклоняющейся в сторону линией... все нации...» [3: 440-441].

Рассматривая становление светского образования в Турции, можно увидеть постепенный, обусловленный политическими и экономическими причинами переход от сугубо исламского, национального образования к интеркультурной образовательной модели, связанной $\mathrm{c}$ постепенной интеграцией турецкого образования в мировое образовательное пространство. Проследив этот путь в истории, можно выделить этапы становления интеркультурного образования в Турции.

Зарождение процессов, постепенное развитие которых привело к возникновению и распространению просветительского движения в Турции, относится к началу XVIII в., когда Османская империя переживала острый социально-экономический кризис, терпела все более сокрушительные военные 
поражения, все больше обнажалась ее отсталость, экономическая, а затем и политическая зависимость от ведущих европейских держав. В социальной структуре турецкого общества происходили серьезные изменения, которые по мнению М.С. Мейера, «...могут быть охарактеризованы как постепенное разложение прежнего сословного строя, размывание перегородок, разделявших общество на множество изолированных групп, складывание более широких социальных общностей, приобретавших определенные черты классов» [6].

В XVIII в. резко усиливаются культурные контакты Турции с Западом, особенно с Францией. К более широкому и глубокому ознакомлению с западноевропейскими странами и Россией, их политико-административным устройством, промышленностью, наукой, техникой турок толкали прежде всего итоги сражений, происходивших на европейских рубежах Османской империи. Этому же способствовало и втягивание Турции в международную торговлю и складывавшийся мировой капиталистический рынок.

Итак, первый этап развития интеркультурного образования в Турции (начало XVIII в.) обозначился открытием иностранных школ в Османской империи с целью повышения экономической и политической конкурентоспособности страны на мировом рынке. Эти школы были военными и создавались по западному образцу, для преподавания в них приглашались иностранные специалисты из Англии, Германии, Австрии, Италии, Швеции и особенно Франции. Основные занятия велись на французском языке через переводчиков, которыми, как правило, являлись греки, славяне или армяне, и изучение этого языка было обязательным наряду с арабским. Помимо прикладной математики, военных наук и уставов, составляющих основу обучения, здесь преподавали географию, историю военного искусства с древних времен до современности и рисование, что было для Турции важным новшеством. Иностранные преподаватели несли черты иной культуры в турецкий уклад жизни и миропонимание, расширяя кругозор обучающихся. Хотя во многих этих школах чтению и письму учили по-турецки.

Оценивая этот этап в развитии светского образования в Турции, нужно обратить внимание на следующие обстоятельства. Во-первых, все светское образование было стимулировано военными и административными реформами и тесно связано с их осуществлением, но вышло за его пределы. Во-вторых, светское специальное образование, в основе своей военное, носило также и общеобразовательный характер и тем самым способствовало осуществлению 
дальнейших реформ в области образования и подготовки государственных деятелей.

Характерным является и то, что все эти учебные заведения создавались правительством по иностранным образцам и при активном участии иностранных советников и специалистов. Кроме того, в этот период начали приниматься меры к непосредственному изучению турками достижений европейской науки и культуры в учебных заведениях стран Запада.

Второй этап XIX вв. был связан с направлением студентов на учебу в Европу при султане Махмуде II и Открытие в Париже Мектеб-и-Османи. В 1839 г. после провозглашения Танзимата тридцать шесть студентов из военных и инженерных училищ были отправлены в европейские столицы Лондон, Париж и Вену, для того чтобы по возвращении получить назначения на военные заводы и предприятия тяжелой промышленности, такие, как артиллерийский, пороховой, оружейный, патронный и литейный заводы, хотя в это время появлялись и студенты, стремившиеся за границей получить светское образование. Помимо военных профессий осуществлялось обучение необходимым обществу гражданским профессиям, а также были подготовлены первые в истории османской науки диссертационные исследования. Вернувшихся из Европы студентов государство определяло на высокие государственные должности, что также способствовало проникновению европейских идей в политическое устройство Турции. Но следует отметить, что получившие в Европе образование турки не предпринимали попыток создания новых учебных и научных учреждений, которые бы стали исследовательской базой для развития отечественной научной традиции [8].

Таким образом, развитие просвещения в Турции в первые два периода стимулировалось рядом внутренних социальных, экономических и политических причин, и также было связано с процессом усиливающегося проникновения в Турцию иностранного капитала и ростом ее международных связей. Эти связи в большой степени способствовали усилению культурного влияния стран Европы на Турцию, что нашло свое отражение прежде всего в реформах системы просвещения. В Турции продолжали существовать и открываться новые иностранные школы. С 1892 г. в Стамбуле было основано русское училище, которое являлось частным учебным заведением с пятилетним сроком обучения (два класса приготовительных и три класса реального училища). В 1907 г. оно было преобразовано в Русское коммерческое училище 
с семилетним сроком обучения (пять общеобразовательных классов и два специальных). Это учебное заведение работало по программе российских коммерческих училищ, приспособленной к местным условиям. В него принимались как русские дети, так и дети подданных других государств. Председателем попечительского совета школы был директор Русского археологического института в Стамбуле, известный русский византинист Ф.И. Успенский [1].

Третий этап развития интеркультурного образования во второй половине XX в. связан с интеграцией Турции в образовательное пространство Европейского Союза. В этом контексте Турция развернула широкомасштабную программу привлечения в турецкие вузы иностранных студентов. Контингент иностранных студентов в Турции с каждым годом наращивается. В университетах Турции в 1998-1999 гг. обучались 18 тысяч 350, в 2008-2009 гг. - 18 тысяч 158, а в 2012-2013 гг. - свыше 40 тысячи иностранных студентов. $[7]$.

Четвертый этап развития интеркультурного образования в Турции конец XX в. - настоящее время. На этом этапе мы видим две интеркультурные тенденции: во-первых, это реализация международных образовательных школьных проектов, как, например, совместный проект между университетом Колумбия и Частной школой Сезгин [15]; во-вторых, это межкультурные детские праздники, например, Всемирный День детей.

Обсуждая первую тенденцию, мы можем привести в качестве примера следующие учебные заведения, которые начали открываться с 1990 годов. Они открывались со стороны государства и частных фондов. В настоящее время в 115 странах функционирует 500 учебных заведений [9]. Эти учебные заведения делают вклад в развитие интеркультурного диалога в области образования. Основная цель этих учебных заведений - ознакомление с турецкой культурой и знакомство с культурой той страны, где они функционируют [9].

В Анталье есть также частная школа, открытая русским бизнесменом, в ней учатся около 60 учеников, в том числе турецкие граждане [11]. У Бурдж колледжа есть 3 школы-побратима: 1 на востоке Турции, 1 в Стамбуле и 1 на Украине. Бурдж колледж имеет договорные отношения с одним из американских лицеев, где его выпускники проходят дальнейшее обучение и профессиональную подготовку. У колледжа есть школы-побратимы из Украины и Америки, происходит взаимообмен учениками на 1-2 недели. 
Приезжающие (дети старше 6 класса) живут не в гостиницах, а домах студентов, именно так начинается диалог между учениками. Здесь учатся студенты из иностранных семей, которые для поступления обязательно должны знать турецкий язык [7, с. 173].

С 2006г. в России ежегодно проводится Всероссийская олимпиада среди обучающихся средних школ по турецкому языку. Организаторами олимпиады при поддержке Посольства Турции в Москве выступают Институт стран Азии и Африки Московского государственного университета, языковой центр «Академия», Российская государственная библиотека,. Председатель Олимпиады, директор Института стран Азии и Африки МГУ профессор Михаил Мейер в своем выступлении на церемонии награждения выразил удовлетворение в связи со значительным ростом интереса к олимпиаде по турецкому языку, которая проводится уже восьмой раз. На церемонии присуждения наград олимпиады состоялось также вручении «Премии турецкого языка имени Ататюрка». Это ежегодная премия, которая присуждается деятелям науки и искусства, политикам и интеллектуалам, внесшим вклад в популяризацию Турции, турецкого языка и культуры. В этом году премия была вручена пресс-секретарю Владимира Путина Дмитрию Пескову, а также известному тюркологу, заведующему кафедрой турецкой филологии института стран Азии и Африки Юрию Щеке. Награду вручил Посол Турции в Москве Айдын Сезгин. В своем выступлении Сезгин назвал проведение таких олимпиад «важнейшим вкладом в светлое будущее двусторонних отношений между Россией и Турцией...Русские, знающие турецкий язык, как и турки, знающие русский язык, вносят огромный вклад в развитие двусторонних отношений, которые уже получили стратегический смысл. В этом контексте для молодежи, владеющей обоими языками, открываются большие возможности», - отметил он. [10].

Обсуждая вторую тенденцию, обратим внимание на традицию детских праздников. Международный день детей отмечается в Турции ежегодно 23 апреля и является уникальным национальным праздником. Официально его учредил в 1920 году первый президент Турецкой Республики Мустафа Кемаль Ататюрк. Ататюрк, считавший детей самым дорогим наследием общества, подарил детям Турецкой Республики этот праздник. С тех пор, 23 апреля, в Турции, традиционно празднуется как день обретения национального суверенитета и детский праздник. В рамках празднования 23 апреля, в школах и 
на стадионах республики проводятся детские фестивали. По случаю праздника в Турцию приглашаются дети из разных стран мира, а также детские творческие коллективы для участия в праздничных церемониях в надежде, что такие празднования будут способствовать в будущем расширению братства и мира среди различных стран.

Дети демонстрируют фольклор своего народа, организуются детские и юношеские международные соревнования, олимпиады, различные семинары. В 2014 году в праздничных мероприятиях Турции приняли участие представители из 19 стран со всего мира. Делегация творческих коллективов из Казани приняла участие в праздничных мероприятиях в турецком городе Анталия, посвященных Международному дню детей. Визит, который состоялся по личному приглашению мэра Анталии Мустафы Акайдына, был организован при поддержке Мэрии Казани. Анталия является городом-побратимом Казани с 2003 года. Также уже десятый год Международный день детей отмечается турецкой диаспорой в Казани. В рамках данного мероприятия проводятся различные конкурсы, викторины, праздничные концерты. Каждый год 23 апреля в Турцию приглашаются дети со всех континентов [12].

В Республике Татарстан в 2009 г. был объявлен конкурс рисунков среди учащихся школ Татарстана «Самый счастливый день моей жизни», приуроченный ко Дню национального суверенитета Турции и Международному дню детей [14].

Выводы. В большинстве современных поликультурных государств происходит сложный и противоречивый процесс смешивания, взаимопроникновения и переплетения культур, что выдвигает перед педагогами этих стран задачу подготовки молодежи к жизни в условиях среды, где надо уметь сотрудничать с людьми разных национальностей, рас, конфессий, разных жизненных ценностей, и эту задачу должно решать теоретически и практически интеркультурное (поликультурное) образование.

Одной из стран, ранее других накопившей богатый и конструктивный опыт организации интеркультурного образования и интеграции иностранных детей является Турция, система образования которой является демократичной; многоуровневой; разнообразной по формам; гарантирует высокий уровень образованности и свободного развития личности и интегрирована в систему образования Европейского Союза. 
Интеркультурное образование и воспитание в Турции воспитывает интеркультурную личность, способную к взаимному признанию национальнокультурной идентичности, сохраняющую свою национальную культуру и индивидуальность, но понимающую многомерность мира и признающую и организующую партнерство представителей различных культур на основе взаимодействующих по принципу дополнительности концепций поэтапной социализации (микро-, мезо- и макроэтапы) и уровневого подхода к формированию интеркультурной компетенции (моно-, меж- и транскультурный уровни).

Реализация интеркультурного образования в системе общего образования Турции происходит на основе организационно-дидактических моделей интеркультурного образования: гуманно-личностной интеркультурно воспитательной; лингвистической образовательной; личностно-социальной.

Интеркультурное образование и воспитание, базирующееся на культурном многообразии мира и направленное на формирование интеркультурной личности, в XXI веке должно занять важное место в образовательной политике любого образовательного учреждения, региона, области, государства для создания в современном полиэтничном и поликультурном обществе атмосферы толерантности и взаимоуважения, нетерпимости к проявлениям ксенофобии, расизма и дискриминации.

\section{Список литературы}

1. АВПР, ф. «Посольство в Константинополе», 1898-1913 гг.,. д. 5187, л.

2. Гачев Г. Национальные образы мира. Космо-Психо-Логос. - М., 1995. $-480 \mathrm{c}$.

3. Гердер И.Г. Идеи к философии истории человечества. М., 1977. 703 с.

4. ЛАВРОВА Т.Б. Предмет исследования в межкультурной коммуникации // Система и среда. Язык. Человек Общество : материалы всерос. науч. конф. Нижний Тагил, 2008.

5. Ласло Э. Пути, ведущие в грядущее тысячелетие. Проблемы и перспективы. [Электронный ресурс]. - URL: http://vivovoco.astronet.ru/VV/PAPERS/HISTORY/VV_HI16W.HTM (дата обращения: 15.08.2012). 
6. Мейер М.С. К вопросу об изменениях в структуре и составе правящего класса Османской империи в XVIII В.// Проблемы истории Турции. М., 1978. С.55

7. Зайцев И.В., Ульченко Н.Ю. "Турция на рубеже XX-XXI веков", ИВ PAH. M., 2008.

8. E.Ihsanoğlu. Tanzimat Öncesi ve Tanzimat Dönemi Osmanlı Bilim ve Eğitim Anlayışı.150 YılındaTanzimat. Ed.H.D.Yıldız.Ankara, 1992, 397-439. S. 375.

9. Toktamış Ateş, Eser Karakaş, İlber Ortaylı. Barış Köprüleri .Dünyaya açılanTürk okulları- Ufuk Kitaplar-2005- sh.109

10. www.aksiyon.com.tr/09.06.14)

11. http://www.trt.net.tr/russian).

12. http://antalyatoday.ru/news/antalya

13. http://etatar.ru/news/

14. www.zaman.com.tr

15. http://www.sezin.k12.tr/ 